\title{
Integrating Civil Participation Into Sustainable Development Practice
}

\author{
Christelle Cazabat ${ }^{1}$
}

\begin{abstract}
The Human Development approach introduced in 1990 by the United Nations Development Programme promoted health, education, freedom and civil participation alongside the more traditional increase of income. Twenty-five years later, as income inequalities grow larger in every part of the world, human development is more relevant than ever. Civil participation in particular has become a central element of sustainable development policies such as the Sustainable Development Goals.

Since the beginning of the new millennium, beneficiaries have been involved in an increasing number of development projects. Civil participation is being recognized as an asset to sustainable development for several reasons including improved efficiency, fairness and resilience. A review of reports from development practitioners and best practices in the field of civil participation towards sustainable development highlighted the importance of engaging individuals and communities to secure lasting and equitable progress. Yet, in a number of cases, results are not up to expectations and obstacles are hindering the potential of such initiatives.

With the aim of reaching the Sustainable Development Goals by 2030, development practitioners can learn from these experiences and integrate civil participation into their programmes more efficiently.
\end{abstract}

\section{Keywords: Civil society, civil participation, human development, development policies, Sustainable} Development Goals

\section{Civil participation in the human development approach}

The human development approach was introduced in 1990 by the United Nations Development Programme as an innovative way to look at development. Inspired by the philosophy of Amartya Sen, human development focuses on individuals rather than on the economy. It seeks to develop people's capabilities so that they may seize the opportunities they choose and fulfil their potential. Income is only one of the means to increase their capabilities, along with freedom, education and health, it is not an end in itself.

Over the last quarter of a century, the human development approach has gained remarkable visibility and influence, changing development strategies all over the world and helping policy-makers keep people's best interests in mind. Since 1990, 24 global, 33 regional, 718 national and 5 sub-national Human Development Reports have been published by the United Nations Development Programme. The governments of 194 countries actively engaged in this process.

Human development is development of the people, for the people and by the people. 
Civil participation plays a central role in this concept. Moving away from the basic needs approach that aims at providing people with primary necessities such as food and access to healthcare, human development does not encourage passive assistance. People are not considered as merely the beneficiaries of public aid, but also as agents of development. People's meaningful participation in the events and processes that shape their lives is a prerequisite for sustainable human development(UNDP, 2013).

Participatory processes are seen as a way to increase the efficiency and sustainability of economic policies and development projects(UNDP, 2000). Sustainable poverty reduction can only be achieved through the self-development of poor countries and poor people. Development strategies should aim to equip people with assets, security and opportunities to produce their way out of extreme deprivation (UNDP, 2005). But participation is not only a tool to improve the efficiency and sustainability of development initiatives. It is also an objective in itself, as a central requirement for a life with dignity(Martha Nussbaum, 2009) and for an equitable society(Jean Drèze and Amartya Sen, 2002).

\section{Civil participation in the global agenda for sustainable development}

The United Nations Development Programme is not the only institution that has promoted civil participation in development strategies. The notion has been included in most major international initiatives for development since the end of the 1980's. In the 1986 Declaration on the Right to Development, the United Nations stated that development aims to improve the well-being of all individuals on the basis of their active, free and meaningful participation(United Nations, 1986).

The 1992 United Nations Conference on Environment and Development held in Rio de Janeiro recognized that efforts to address environmental issues should include participation by concerned citizens. Governments were requested to encourage civil participation by providing access to public information, raising national awareness and offering opportunities to participate in decision-making processes(UNCED, 1992). The Rio Declaration further claimed that the full participation of women, youth, indigenous people and local communities were essential to achieve sustainable development.

In 2000, the United Nations Millennium Declaration reaffirmed that democratic and participatory governance based on the will of the people was the best way to assure human rights. The signatories resolved to promote the empowerment of women, to develop partnerships with the private sector and with civil society organizations and to ensure more inclusive political processes allowing participation by all citizens(United Nations, 2000).

The Paris Declaration on Aid Efficiency(OECD, 2005), the Accra Agenda for Action(OECD, 2008) and the Busan Partnership for Effective Development(OECD, 2011) confirmed the international community's agreement that development strategies should be more participatory in the new millennium.

\section{The practice of participation for development}

In practice as in theory, populations have been progressively included in 
international and national initiatives for development since the 1990's. Their participation started by way of non-governmental organizations and more recently extended to the private sector and to new forms of individual participation supported by the spread of information and communication technologies.

Non-governmental organizations have played an increasingly important part in development at the local, national and global levels. Their relationship with governments often started as a challenge in the 1990's. In African, Asian and South American countries undergoing a democratization process, the newly acquired right to association was seized by opposition movements that were previously prohibited. Progressively, governments experimented by collaborating with non-governmental organizations while officially recognizing their role in political and public life at local and national levels. In Africa and South America, partnerships between governments and civil society organizations for the provision of basic public services are now common(J.N. Maupin, 2009).

At the international level, recognition came gradually, with a significant threshold passed after 2000. Non-governmental organizations evolved from being considered a source of information or as operating partners to being involved in the elaboration, implementation and evaluation of international development initiatives. In 2004, 74 percent of the projects funded by the World Bank involved non-governmental organizations, up from 18 percent in 1990(World Bank, 2005). At the same time, the number of non-governmental organizations in consultative status with the Economic and Social Council of the United Nations grew exponentially: 45 percent of them were admitted between 2010 and 2014 and 77 percent were admitted after 2000(ECOSOC, 2014).

More recently, private companies have taken part in delivering development strategies and humanitarian interventions, sending funds, supplies or human resources to support the efforts of governments and international organisations. One of the first corporate social responsibility partnerships was launched in 1995 between UNICEF and Starwood Hotels and Resorts. Hotel guests were invited to add one US\$ to their hotel bills as a donation to UNICEF, raising over US\$ 35 million in 20 years(UNICEF, 2016). UNICEF now partners with nearly 200 private companies contributing US $\$ 100,000$ or more to its programmes. The United Nations Global Compact is the world's largest corporate sustainability initiative, with over 12,000 active signatories from 170 countries who voluntarily committed to supporting their community and respecting the principles of human rights, decent work, environmental sustainability and transparency. The initiative was launched in 2000 and has generated increased commitment ever since, as illustrated in figure 1. 


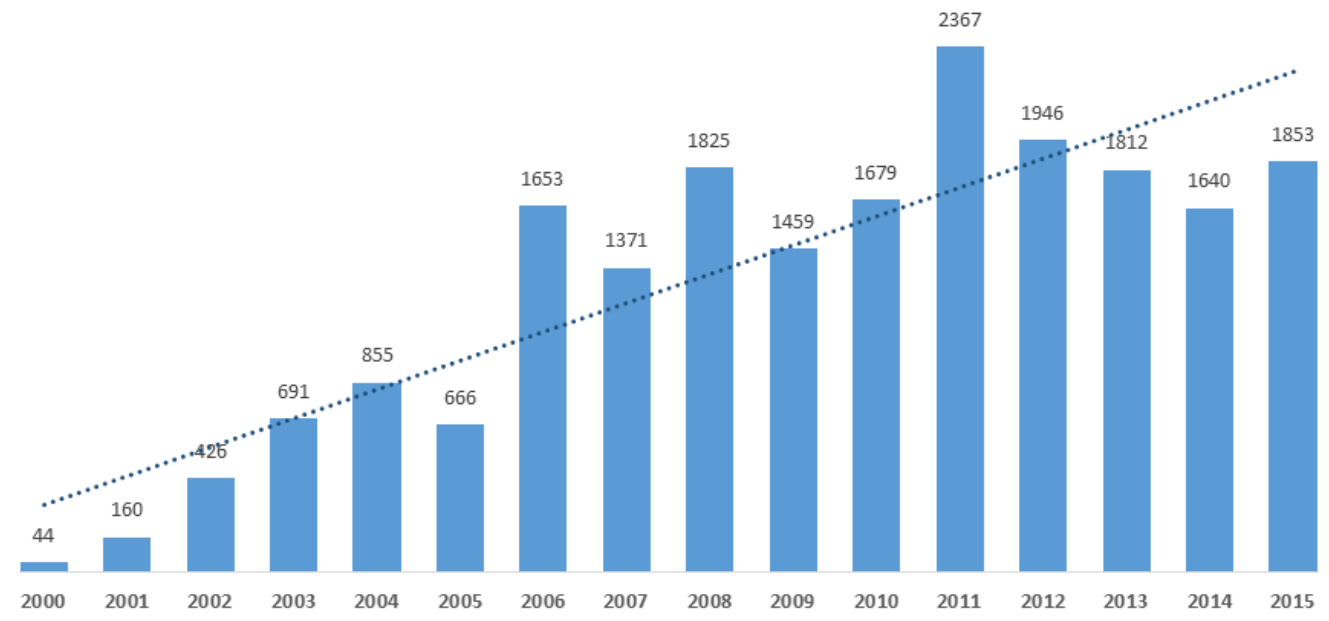

Figure 1: United Nations Global Compact new signatories per year(UN Global Compact, 2016).

The expansion of corporate social responsibility can be interpreted as the influence of citizen-consumers on the private sector. In a competitive global market, consumers can encourage responsible behaviours from the private sector by preferring ethical products and practices. An analysis of 394 Western European and Latin American corporate signatories to the United Nations Global Compact showed that the influence of norms and peers is more important than government regulations in encouraging corporate decision makers to engage in sustainability(Luis A. Perez-Batres, Van V. Miller, \& Michael J. Pisani, 2011).

Individuals have seen their ability to influence public and political life expand considerably since the beginning of the new millennium. The spread of the Internet and of mobile technologies have opened new channels for civil participation. E-government services facilitate exchanges between governments and their population, even in remote areas. Online petitions allow people to support or oppose projects that are relevant to them, whether nearby or across the world. In 2010, two million people from different countries signed an online petition to ban politicians convicted of crimes from running for office in Brazil(Avaaz, 2016). Mobile phones and web platforms help protesters organize mass events such as the 2014 People's Climate March which gathered 400,000 people in Manhattan. Crowdfunding lets people contribute small amounts of money towards a philanthropic project in their own neighbourhood or on another continent.

Volunteering is another means of participation for individuals that has developed in recent years. Many governments have now adopted strategies to catalyse and encourage volunteering for social initiatives. In the United States, the Office of Social Innovation and Civic Participation was created by the White House in 2009 to support social initiatives led by non-profit or non-governmental organizations, foundations and social entrepreneurs. Peru passed a national law to promote volunteerism in 2007 and Argentina a comparable law in 2010. During the Haiti earthquake in 2010, a community of volunteers created an online portal in partnership with the government, international organizations and the private sector to centralize disaster response operations(UNDESA, 
2014). The Sahana Haiti 2010 Earthquake Disaster Response Portal provided a registry to track relief efforts and avoid duplication, a request management system, a victim identification registry and a translation service.

The United Nations Volunteers programme is entirely dedicated to promoting volunteerism worldwide and engaging volunteers in development and peace building projects. The number of United Nations Volunteers per year grew from 4,000 in 1999 to 6,325 in 2014. Most United Nations Volunteers are men and come from developing countries(UNV, 2014). The programme also operates an online volunteering platform which brings together civil society organizations, United Nations or governmental agencies requesting support from volunteers, and volunteers from around the world who can dedicate part of their time to supporting these entities online. In 2014, 10,887 online volunteers participated in this programme, supporting 2,433 organizations. Most online volunteers were women and came from developing countries.

\section{Civil participation in the Sustainable Development Goals}

The 2030 Agenda for Sustainable Development, adopted in September 2015 by the United Nations, is the result of these evolutions in civil participation. Its elaboration started in 2012, at the United Nations Conference on Sustainable Development in Rio de Janeiro. In the conference's outcome declaration The Future $W e$ Want, governments recognized that people's opportunities to influence their lives and future, participate in decision making and voice their concerns were fundamental for sustainable development(UNCSD, 2012). They also called for the drafting of new Sustainable Development Goals to take over the Millennium Development Goals ending in 2015.

The preparation process was itself much more participatory than the Millennium Development Goals. From 2012 to 2015, several dozen national, regional, global and thematic consultations brought together multinational, governmental, non-governmental and academic partners to draft proposals for the new Sustainable Development Goals. The individuals, non-governmental organizations and private sector companies around the world were able to vote for the areas they consider personal priorities, through the web platform My World or through paper surveys distributed by United Nations Volunteers. Nearly 8.5 million votes had been recorded by September 2015 .

The 17 Sustainable Development Goals integrate human development principles in a much more comprehensive way than their predecessors, the Millennium Development Goals. The place of participation which, in the Millennium Development Goals, was restricted to women's empowerment, is much more explicit in the Sustainable Development Goals. A target is now dedicated to ensuring women's full and effective participation and equal opportunities for leadership at all levels of decision-making in political, economic and public life"(United Nations, 2015b). Greater participation from all groups of population is covered in Goal 16, which aims to ensure responsive, inclusive, participatory and representative decision-making at all levels as well as public access to information.

The United Nations SDG Action Campaign is an initiative launched to promote the engagement of civil society and citizens in the implementation of the 2030 Agenda for Sustainable Development. Building on the participatory elaboration process that led to 
the Sustainable Development Goals, the campaign aims at "Moving from global conversation to global action"(United Nations, 2016). It is meant to empower citizens through engagement activities and ensure that individuals and organizations who can help implementing the Sustainable Development Goals are involved. It will also support citizen-driven accountability via crowdsourcing and grass-roots mobilization and seek to maximize the impact of citizen voice. This initiative aims to make civil participation more significant than ever in the new global agenda for sustainable development.

\section{Tackling obstacles that hinder civil participation}

These evolutions set an encouraging environment for civil participation to deepen in coming years. Yet experience from previous participatory development initiatives shows that obstacles remain and hinder their efficiency, limiting anticipated positive results. International donors have reported on the insufficient capacities of local non-governmental organizations to take an active part in their large-scale projects(IRAM, 2012). In developing countries, civil society partners are not always trained to prepare financial reports that meet international donors' requirements, for instance. The importance of including capacity building components in development programmes has been highlighted.

Another obstacle to full and fair civil participation at the global level is the overrepresentation of developed countries in international fora and in new channels of participation. Over half of the non-governmental organizations in consultative status with the United Nations Economic and Social Council come from Europe and North America. Asian organizations represent only 17 percent of this contingent, African organizations 14 percent and Latin American organizations 5 percent(UNDESA, 2016). On the Internet as well, developing countries are under-represented. Over 85 percent of the user-generated content listed on Google is produced in the United States of America, in Canada or in Europe(World Bank, 2016). Although only 6 percent of the world's population are native English speakers, 56 percent of online content is in English(UNDESA, 2014).

Inequalities are equally obstructing participation at the national level. In spite of improvements in the last decades, women still account for less than a quarter of national parliamentary seats in global averages(United Nations, 2015a). In 2013, there were 200 million fewer women than men online, a gender gap particularly significant in developing countries(ITU and UNESCO, 2015). Women are 21 percent less likely to own a mobile phone than men. Older people and lower-income groups are also less likely to use information and communication technologies. Migrants, women and poor people generally volunteer less(M. Mascherini, Vidoni, D., Manca, A.R., 2011). Economic, social and sometimes legal obstacles still limit civil participation for certain sub-groups of a population.

The Sustainable Development Goals aim at removing these barriers. They call for strengthened participation of developing countries in global institutions and for their enhanced representation in global economic and financial decision making, leading to more effective, credible, accountable and legitimate institutions. They insist on the need to provide universal access to the Internet and to information and communication 
technologies, particularly for women.

The 2030 Agenda for Sustainable Development calls for governments to work closely with volunteer groups and recognises the contribution of non-governmental organizations and of the private sector in sustainable development. The human development approach advocates for development by the people. Both approaches should therefore be seen as complementary. One of the roles for governments in the implementation of the 2030 Agenda will be to facilitate contributions from all stakeholders. The human development approach can highlight the potential role people could - and should - play in achieving progress. The Sustainable Development Goals provide a necessary framework for governments to ensure that this potential is realized.

\section{References}

Avaaz. (2016). Avaaz.org: The world in action. Retrieved from https://avaaz.org

World Bank. (2005). Civil Society Engagement: Review of fiscal years 2002-2004. Washington DC.

World Bank. (2016). World Development Report 2016 : Digital Dividends. Retrieved from http://wwwwds.worldbank.org/external/default/WDSContentServer/WDSP/IB/2016/01/13/090224b0840 5ea05/2_0/Rendered/PDF/World0developm0000digital0dividends.pdf

UN Global Compact. (2016). United Nations Global Compact website. Retrieved from https://www.unglobalcompact.org

ECOSOC. (2014). List of non-governmental organizations in consultative status with the Economic and Social Council as of 1 September 2014. Retrieved from http://csonet.org/content/documents/E2014-INF-5\%20Issued.pdf

IRAM. (2012). Evaluation du Fonds Social de Développement. Yaounde.

M. Mascherini, Vidoni, D., Manca, A.R. (2011). Exploring the Determinants of Civil Participation in 14 European Countries: One-Size-Fits None. European Sociological Review, 27(6), 790-807.

J.N. Maupin. (2009). 'Fruit of the accords': Healthcare reform and civil participation in Highland Guatemala. Social science \& medicine, 68(8), 1456-1463.

United Nations. (1986). Declaration on the Right to Development. A/RES/41/128. Retrieved from http://www.un.org/documents/ga/res/41/a41r128.htm

United Nations. (2000). United Nations Millennium Declaration. New York.

United Nations. (2015a). The Millennium Development Goals Report 2015. Retrieved from http://www.un.org/millenniumgoals/2015_MDG_Report/pdf/MDG\%202015\%20rev\%20\%28J uly $\% 201 \% 29$.pdf

United Nations. (2015b). Transforming our world: the 2030 Agenda for Sustainable Development. Resolution adopted by the General Assembly on 25 September 2015. Retrieved from http://www.un.org/ga/search/view_doc.asp?symbol=A/RES/70/1\&Lang=E

United Nations. (2016). SDG Action Campaign website. Retrieved from http://sdgactioncampaign.org/

Martha Nussbaum. (2009). Capabilities as fundamental entitlements: Sen and social justice In K. Schneider (Ed.), From Employability Towards Capability (pp. 15-43): Klaus Schneider.

OECD. (2005). Paris Declaration on Aid Efficiency. Paris.

OECD. (2008). Accra Agenda for Action. Accra.

OECD. (2011). Busan Partnership for Effective Development Co-operation. Busan.

Luis A. Perez-Batres, Van V. Miller, \& Michael J. Pisani. (2011). Institutionalizing sustainability: an empirical study of corporate registration and commitment to the United Nations global compact guidelines. Journal of Cleaner Production, 19(8), 843-851.

Jean Drèze and Amartya Sen. (2002). India: Development and Participation: Oxford University Press.

UNCED. (1992). Report of the United Nations Conference on Environment and Development. Rio Declaration on Environment and Development. Rio de Janeiro.

UNCSD. (2012). The Future We Want: Outcome document adopted at the United Nations Conference on Sustainable

Development.

Retrieved

from 
http://www.uncsd2012.org/content/documents/727The \%20Future $\% 20$ We $\% 20$ Want $\% 2019 \% 20$ June $\% 201230 \mathrm{pm} . \mathrm{pdf}$

UNDESA. (2014). United Nations e-government survey 2014: e-government for the future we want. ST/ESA/PAD/SER.E/188. Retrieved from https://publicadministration.un.org/egovkb/Portals/egovkb/Documents/un/2014-Survey/EGov_Complete_Survey-2014.pdf

UNDESA. (2016). NGO Branch, Office for ECOSOC Support and Coordination website. Retrieved from http://csonet.org/

UNDP. (2000). Human Development Report 2000: Human Rights and Human Development. Retrieved from http://hdr.undp.org/en/content/human-development-report-2000

UNDP. (2005). Human Development Report 2005: International cooperation at a crossroads: Aid, trade and security in an unequal world. Retrieved from http://hdr.undp.org/en/content/humandevelopment-report-2005

UNDP. (2013). Human Development Report 2013: The Rise of the South: Human Progress in a Diverse World.

Retrieved

from http://hdr.undp.org/sites/default/files/reports/14/hdr2013_en_complete.pdf

ITU and UNESCO. (2015). The state of broadband 2015: broadband as a foundation for sustainable development. Retrieved from http://www.broadbandcommission.org/Documents/reports/bbannualreport2015.pdf

UNICEF. (2016). Check out for Children (Starwood Hotels and Resorts). Retrieved from http://www.unicef.org/corporate_partners/index_starwood.html

UNV. (2014). Statistical and financial information for 2014. Retrieved from http://www.unv.org/annualreport-2014/pdf/Statistical_information.pdf 